\title{
Nearshore mixing and nutrient delivery along the western Antarctic Peninsula
}

\author{
D. REIDE CORBETT ${ }^{1,2}$, JARED CRENSHAW ${ }^{1}$, KIMBERLY NULL $^{1,3}$, RICHARD N. PETERSON $^{4}$, \\ LEIGHA E. PETERSON ${ }^{4}$ and W. BERRY LYONS ${ }^{5}$ \\ ${ }^{1}$ East Carolina University, Greenville, NC 27858, USA \\ ${ }^{2}$ University of North Carolina Coastal Studies Institute, Wanchese, NC 27981, USA \\ ${ }^{3}$ Current address: Moss Landing Marine Laboratories, Moss Landing, CA 95039, USA \\ ${ }^{4}$ Department of Coastal and Marine Systems Science, Coastal Carolina University, Conway, SC 29526, USA \\ ${ }^{5}$ School of Earth Sciences and Byrd Polar and Climate Research Center, Ohio State University, Columbus, OH 43210, USA \\ corbettd@ecu.edu
}

\begin{abstract}
The surface waters of the Southern Ocean play a key role in the global climate and carbon cycles by promoting growth of some of the world's largest phytoplankton blooms. Several studies have emphasized the importance of glacial and sediment inputs of Fe that fuel the primary production of the Fe-limited Southern Ocean. Although the fertile surface waters along the shelf of the western Antarctic Peninsula (WAP) are influenced by large inputs of freshwater, this freshwater may take multiple pathways (e.g. calving, streams, groundwater discharge) with different degrees of water-rock interactions leading to variable Fe flux to coastal waters. During the summers of 2012-13 and 2013-14, seawater samples were collected along the WAP, near Anvers Island, to observe water column dynamics in nearshore and offshore waters. Tracers $\left({ }^{223,224} \mathrm{Ra}\right.$, ${ }^{222} \mathrm{Rn},{ }^{18} \mathrm{O},{ }^{2} \mathrm{H}$ ) were used to evaluate the source and transport of water and nutrients in coastal fjords and across the shelf. Coastal waters are compared across two field seasons, with increased freshwater observed during 2014. Horizontal mixing rates of water masses along the WAP ranged from $110-3600 \mathrm{~m}^{2} \mathrm{~s}^{-1}$. These mixing rates suggest a rapid transport mechanism for moving meltwater offshore.
\end{abstract}

Received 4 April 2016, accepted 24 February 2017, first published online 10 May 2017

Key words: horizontal eddy diffusivity, land-ocean interface, meltwater, radium isotopes

\section{Introduction}

Over the past one hundred years, average global temperatures have been increasing. The most drastic warming has taken place in climate-sensitive regions at high latitudes, including the western Antarctic Peninsula (WAP; Schofield et al. 2010; Fig. 1) where annual mean atmospheric temperatures have increased by $\sim 3^{\circ} \mathrm{C}$ over the past 60 years (King 1994, Turner et al. 2005). Due to recent warming, glaciers between $64^{\circ} \mathrm{S}$ and $66^{\circ} \mathrm{S}$ are currently receding at an average rate of $\sim 57 \pm 25 \mathrm{~m} \mathrm{y}^{-1}$ (Cook et al. 2005). Warming air temperatures have been concurrent with sea ice reduction, with many glaciers having nearfrontal surface lowering of $0.28 \pm 0.03 \mathrm{~m} \mathrm{y}^{-1}$ over the past 40 years (Kunz et al. 2012). This in turn has increased glacial melt inputs that have the potential to impact salinity and temperature dynamics in surface waters along the shoreline (Ducklow et al. 2012). The input of glacial melt can also lead to increases in many biogeochemically important elements (e.g. N, P, C, Si, Fe) into the coastal ocean (Wadham et al. 2013). Surface waters of the Southern Ocean play a key role in global climate and carbon cycles by hosting some of the world's largest phytoplankton blooms, which sequester up to one billion metric tons of $\mathrm{CO}_{2}$ per year (Takahashi et al. 2012).

Continentally derived freshwater inputs often enter coastal waters during meltwater pulses along the WAP. This meltwater can enter the nearshore coastal zone through calving, periglacial stream flow, basal melt and subglacial melt, which passes over or through sediments or other geologic material before reaching the ocean. These pulses create large freshwater lenses that can extend as deep as $50 \mathrm{~m}$ into the water column, and as far as $100 \mathrm{~km}$ offshore (Dierssen et al. 2002). Meltwater pulses have the potential to develop density gradients that can drive surface currents, resulting in the lateral transport of continentally derived nutrients and micronutrients (e.g. Fe) offshore (Dierssen et al. 2002, Moffat et al. 2008). Dierssen et al. (2002) found that $>70 \%$ of phytoplankton blooms observed offshore of Anvers Island occurred shortly after pulses of meltwater discharged from local glaciers into the surface ocean.

Recent studies (Bhatia et al. 2013, Hawkings et al. 2014, Lyons et al. 2015) have emphasized the potential importance of direct and indirect glacial inputs to Fe budgets in polar 


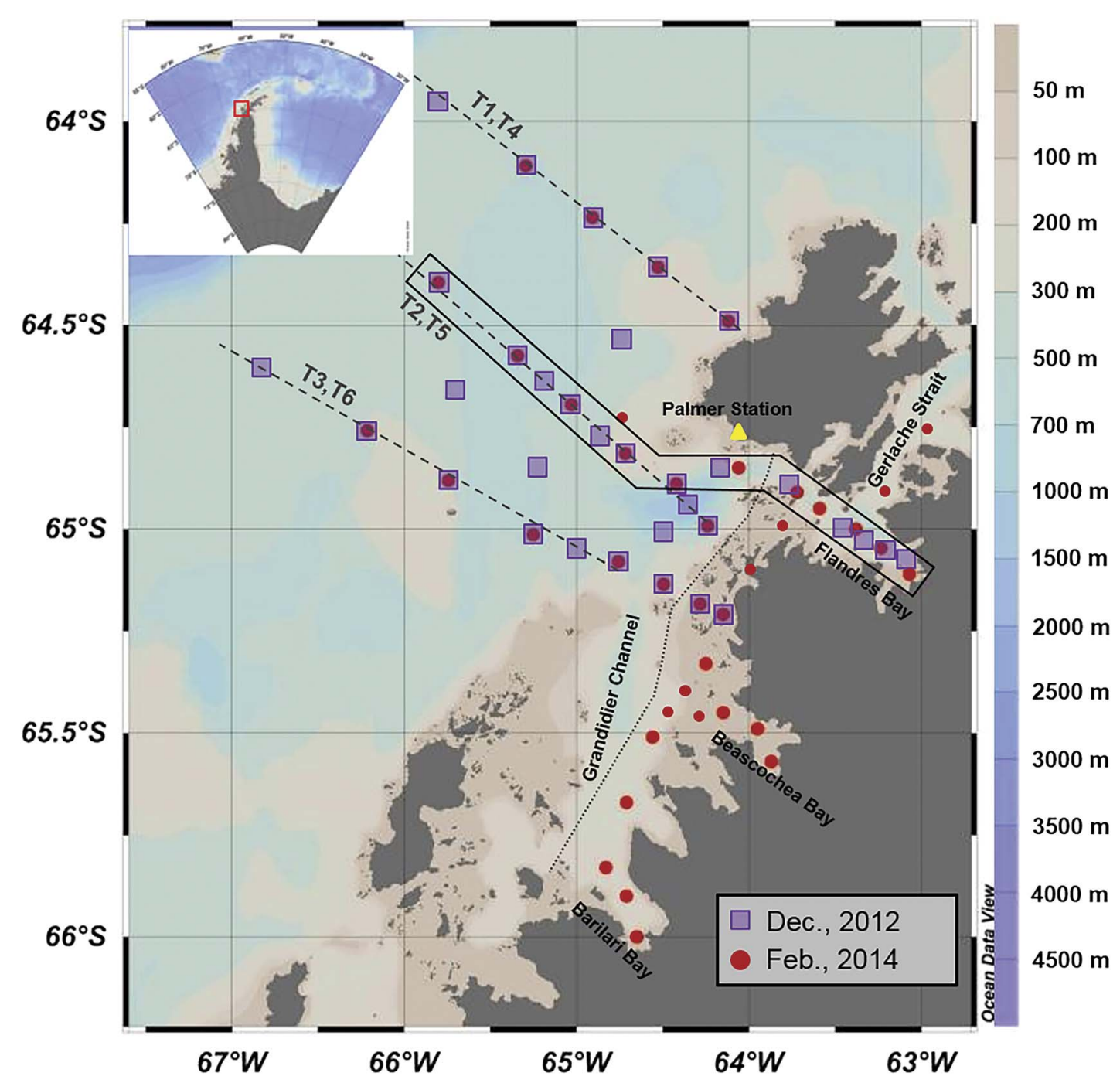

Fig. 1. Sample collection sites and transects (dashed line) during the 2012 (blue squares; T1, 2, 3) and 2014 (red circles; T4, 5, 6) cruises offshore of the western Antarctic Peninsula. Dotted line represents the delineation of nearshore versus offshore samples. Box encompassing sites within Flandres Bay and the T2,T5 line were used to produce the density cross-section (see Fig. 4).

Yellow triangle denotes the approximate location of Palmer Station.

regions, and how these inputs may fuel primary productivity in Fe-limited environments such as the Southern Ocean (Takahashi et al. 2012). Fertile surface waters along the shelf of the WAP are influenced by large inputs of glacial melt from the peninsula (Dierssen et al. 2002). The objective of this study was to evaluate the transport of nutrient-rich meltwaters from the Antarctic continent into the biologically productive coastal waters along the WAP utilizing a suite of naturally occurring stable- and radioisotopes as tracers of terrestrially derived water masses.

\section{Study area}

The WAP extends northward from the western Antarctic continent. This region is the warmest in the Antarctic and one of the most rapidly warming regions in the world
(Vaughan et al. 2003, Steig et al. 2009). The rugged topography and warmer maritime climate of the peninsula differentiates the WAP from other regions of the continent. Air temperatures along the western coast of the WAP are dominated by the influence of the Bellingshausen Sea, causing air temperatures to be $\sim 7^{\circ} \mathrm{C}$ warmer than the eastern coast of the peninsula, which is influenced by the cooler Weddell Sea (Morris \& Vaughan 2003). This region has seen an increase in July (i.e. midwinter) temperatures of $7.2^{\circ} \mathrm{C}$ from $1951-2008\left(0.124 \pm 0.044^{\circ} \mathrm{C} \mathrm{yr}^{-1}\right.$; Ducklow et al. 2012).

The continental shelf of the WAP is $\sim 200 \mathrm{~km}$ wide near Anvers Island and has an average depth of $\sim 450 \mathrm{~m}$. The aforementioned depth excludes many of the deep canyons that incise the continental shelf, such as the Palmer Deep that reaches a maximum depth of $\sim 1500 \mathrm{~m}$. Several 


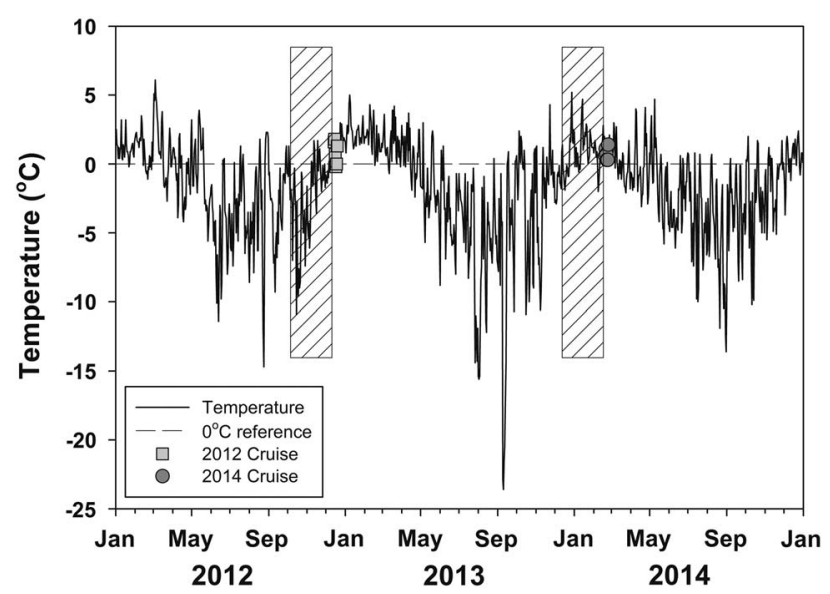

Fig. 2. Air temperature measured at Palmer Station from 2012 through to the end of 2014. Offshore sampling took place in December 2012 (squares) and March 2014 (circles). Hatched boxes are used to illustrate temperatures two months prior to the cruise. Note temperatures below freezing prior to 2012 cruise and above freezing prior to 2014.
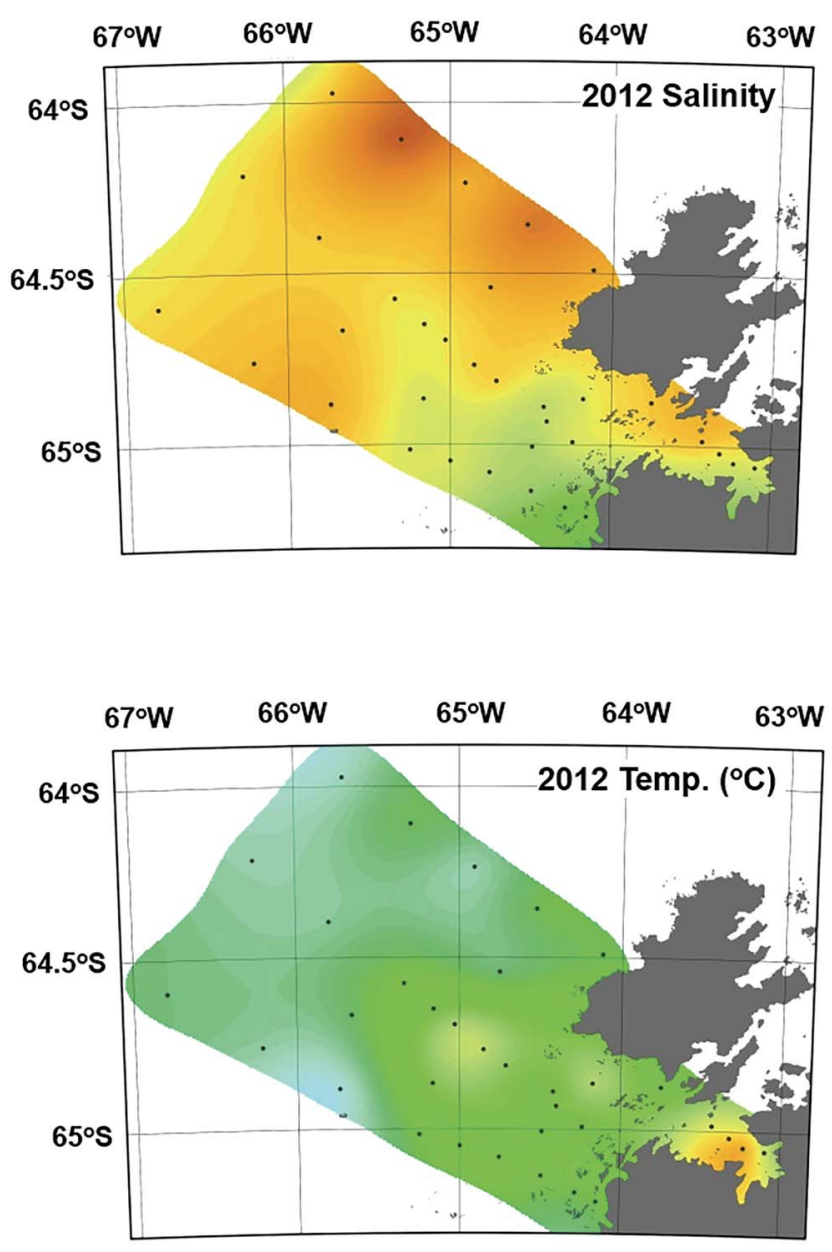

glacially carved fjords line the coast of the WAP and were also sampled as part of this research. Flandres Bay is protected from the open ocean by Anvers Island and several smaller islands. The $16 \mathrm{~km}$ wide fjord is flanked by mountains on both sides and reaches depths $>600 \mathrm{~m}$. The mouth of Flandres Bay opens to the Gerlache Strait. Barilari Bay and Beascochea Bay are both similarly flanked by rugged mountains, and open to the Grandidier Channel (Fig. 1).

Surface water characteristics along the WAP vary widely on a seasonal basis. During the summer, Antarctic Surface Water (AASW) found above the permanent thermocline $(\sim 150 \mathrm{~m})$, ranges in temperature from $-1.5-1.0^{\circ} \mathrm{C}$ and in salinity from $33.0-33.7$ (Klinck et al. 2004). During the winter, a relatively cooler and saltier water mass develops near the surface (Winter Water), generally cooler than $-1.8^{\circ} \mathrm{C}$ with a salinity of $\sim 34.1$ (Klinck et al. 2004). Subpycnocline waters are classified as Circumpolar Deep Water (CDW), subdivided into upper CDW and lower CDW. CDW ranges in temperature
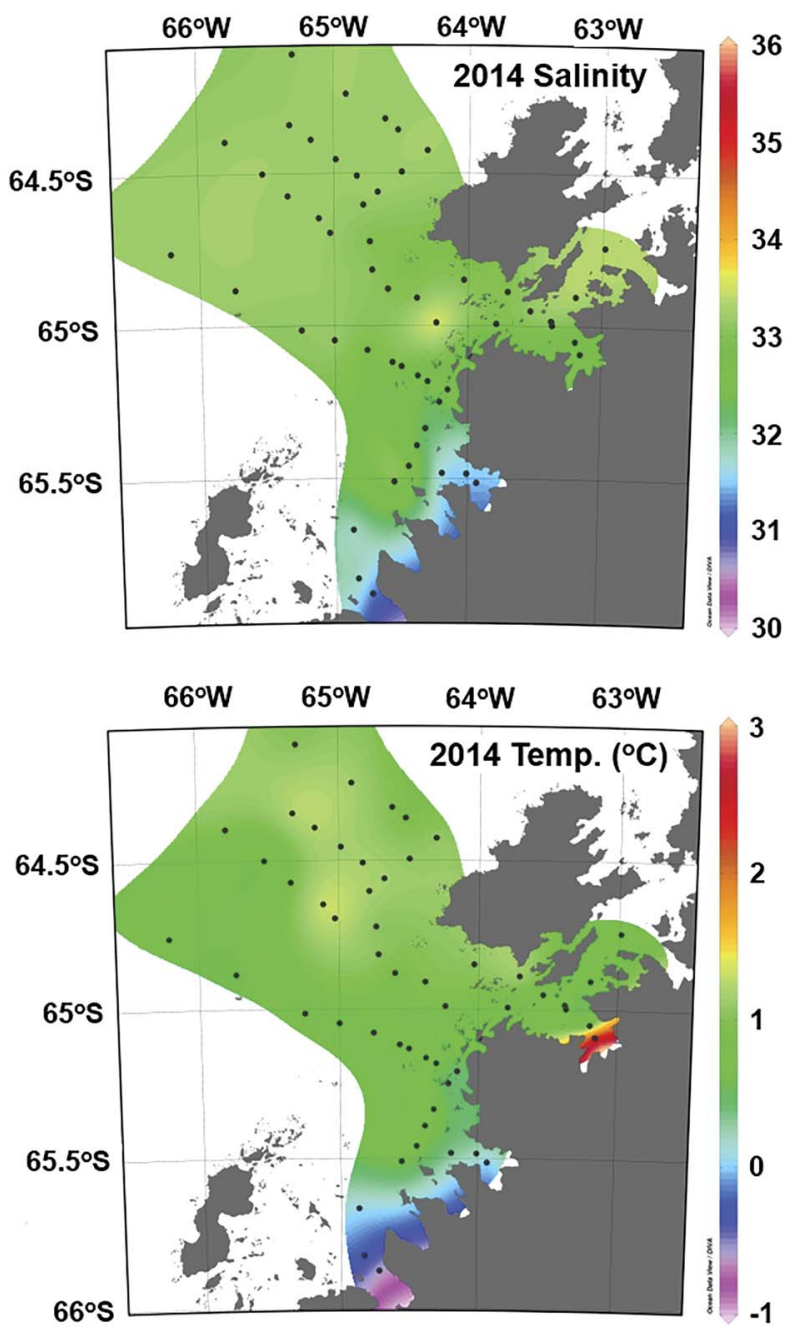

Fig. 3. Spatial distribution of salinity and temperature in surface waters during the 2012 and 2014 cruises. Note the lower salinities and higher temperatures nearshore during the 2014 relative to the 2012 cruise. 

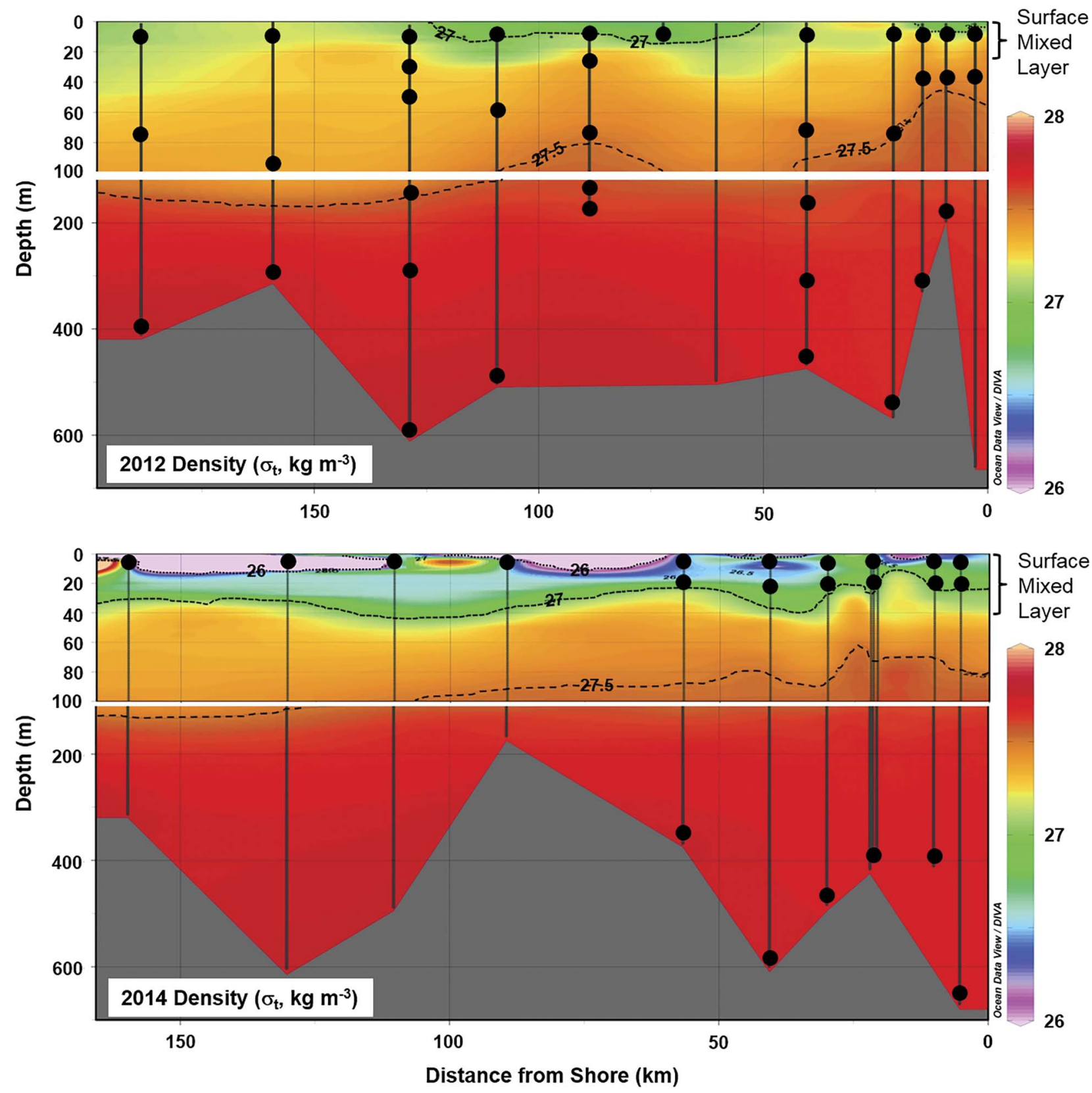

Fig. 4. Density cross-section starting inside Flandres Bay and moving across the shelf on T2 (2012) and T5 (2014). Refer to box area in Fig. 1 for cross-section sampling sites. Dashed lines are isopycnals, vertical lines and black circles refer to CTD cast sites and sampling depths. Note increased depth and gradient during 2014.

from $1.0-2.0^{\circ} \mathrm{C}$ and has salinities of 34.6-34.7. Upper CDW has frequent incursions into coastal waters along the continental shelf, mixing with surface waters (Klinck et al. 2004, Meredith et al. 2013).

Cyclonic circulation patterns along the WAP were identified in early oceanographic studies, and further described by Savidge \& Amft (2009). Long-term in situ measurements along the peninsula suggest that a cyclonic cell rotates around Anvers Island. Surface waters offshore of Anvers Island flow south and form part of the Antarctic Peninsula Coastal Current (APCC), an along-shore surface current that occurs on the west coast of the peninsula during the summer months (Moffat et al. 2008). The development of the APCC is thought to be initiated by meltwater inputs along the peninsula, although the origin of these waters is poorly understood. The APCC has been observed as far north as Brabant and Anvers islands (Savidge \& Amft 2009) and flows southward, eventually making its way into Marguerite Bay and farther south (Moffat et al. 2008). In the Gerlache Strait, surface currents have been observed moving north toward the Bransfield Strait (Savidge \& Amft 2009). 
Table I. Groundwater and surface runoff (i.e. streams) endmember values from the 2012 and 2014 field seasons. Data presented are mean and standard error.

\begin{tabular}{lcc}
\hline Tracer/nutrient & Groundwater $(n=29)$ & Surface runoff $(n=16)$ \\
\hline Salinity & $1.3 \pm 0.3$ & $0.03 \pm 0.01$ \\
Temperature $\left({ }^{\circ} \mathrm{C}\right)$ & $2.6 \pm 0.2$ & $2.6 \pm 0.5$ \\
$\delta^{18} \mathrm{O}(\%)$ & $-11.4 \pm 0.4$ & $-10.0 \pm 0.6$ \\
$\delta \mathrm{D}(\%)$ & $-89.4 \pm 3.0$ & $-78.2 \pm 4.7$ \\
${ }^{22} \mathrm{Ra}\left(\mathrm{dpm} \mathrm{m}^{-3}\right)$ & $83 \pm 22$ & $57 \pm 15$ \\
${ }^{223} \mathrm{Ra}\left(\mathrm{dpm} \mathrm{m}^{-3}\right)$ & $3.2 \pm 0.9$ & $8.2 \pm 4.4$ \\
${ }^{222} \mathrm{Rn}_{\left(\mathrm{dpm} \mathrm{l}^{-1}\right)}$ & $33 \pm 19$ & $66 \pm 34$ \\
$\mathrm{NO}_{3}^{-}+\mathrm{NO}_{2}^{-}(\mu \mathrm{M})$ & $57.5 \pm 3.5$ & $33.2 \pm 10.6$ \\
$\mathrm{NH}_{4}^{+}(\mu \mathrm{M})$ & $23.5 \pm 7.0$ & $13.9 \pm 2.4$ \\
$\mathrm{HPO}_{4}^{-2}(\mu \mathrm{M})$ & $2.6 \pm 0.5$ & $1.2 \pm 0.2$ \\
$\mathrm{H}_{4} \mathrm{SiO}_{4}(\mu \mathrm{M})$ & $18.6 \pm 3.0$ & $37.9 \pm 12.2^{\mathrm{a}}$ \\
$\mathrm{dFe}(\mu \mathrm{M})$ & $35.4 \pm 7.1^{\mathrm{b}}$ & $0.47 \pm 0.12^{\mathrm{c}}$ \\
\hline
\end{tabular}

${ }^{\mathrm{a}} n=12,{ }^{\mathrm{b}} n=18,{ }^{\mathrm{c}} n=6$.

\section{Methods}

\section{Sample collection}

During the summers of 2012-13 and 2013-14 (14-19 December 2012 and 19-24 February 2014, respectively; Fig. 2), large volume seawater samples (280-3601) were collected along the WAP aboard the RV Laurence $M$. Gould to observe water column and tracer dynamics in nearshore and offshore environments (Fig. 1). Groundwater and surface runoff from glacial melt (e.g. streams) samples (20-1501) were collected while at Palmer Station following similar shipboard measurements. During each field season, offshore and nearshore seawater was collected from one to three depths (surface, mid-depth and bottom) along three transects (2012: T1, T2, T3; 2014: T4, T5, T6) and within glacial fjords. Due to limited ship time in 2014, sample collection was focused on surface water collection. Surface water samples were collected in the upper $10 \mathrm{~m}$ of the water column. Mid-depth and bottom water samples were collected just above the pycnocline $(30-60 \mathrm{~m})$ and $\sim 10 \mathrm{~m}$ above the bottom, respectively.
Groundwaters were collected using a custom drive-point piezometer lined with Teflon tubing. Surface runoff was collected from several different streams via a peristaltic pump near Palmer Station prior to discharge into surface waters. Samples were analysed for a suite of parameters, including radium isotopes $\left({ }^{223,224} \mathrm{Ra}\right),{ }^{222} \mathrm{Rn}, \delta^{18} \mathrm{O}$ and $\delta \mathrm{D}$, and nutrient and trace metal concentrations $\left(\mathrm{NO}_{3}{ }^{-}+\mathrm{NO}_{2}{ }^{-}\right.$, $\mathrm{NH}_{4}{ }^{+}, \mathrm{HPO}_{4}{ }^{2-}, \mathrm{H}_{4} \mathrm{SiO}_{4}$, total dissolved $\mathrm{Fe}$ ).

At each nearshore and offshore site, the CTD-rosette (Seabird SBE911) was lowered multiple times from the ship to within a few metres of the sea floor. Temperature (SBE3), salinity (SBE4), density, beam transmission (Wet Labs C-Star), oxygen (SBE43) and fluorescence (Wet Labs ECO) were recorded. Along the cruise track during each field season, a hull mounted acoustic doppler current profiler (ADCP) was used to measure current velocities throughout the water column.

\section{Radium isotopes}

Radium was quantitatively concentrated from water samples by gravity filtering (rate of $<11 \mathrm{~min}^{-1}$ ) onto $\mathrm{MnO}_{2}$-coated acrylic fibre (i.e. Mn fibres). Fibres were then rinsed with radium-free water, partially dried with compressed air and immediately analysed for total ${ }^{223} \mathrm{Ra}$ and ${ }^{224} \mathrm{Ra}$ using a radium delayed coincidence counter (RaDeCC; Moore \& Arnold 1996). At least four weeks (eight half-lives of ${ }^{224} \mathrm{Ra}$ ) after this initial count, fibres were recounted via the RaDeCC for ${ }^{224} \mathrm{Ra}$ supported by ${ }^{228} \mathrm{Th}$ sorbed to the fibres. Excess, or unsupported ${ }^{224} \mathrm{Ra}$ (presented herein), is taken as the difference between the initial count (total) and the second measurement (supported). ${ }^{223} \mathrm{Ra}$ is presented as total, not corrected for ${ }^{227} \mathrm{Ac}$ (negligible in most instances). Detector efficiencies and analytical precision $\left(0.08 \mathrm{dpm} \mathrm{m}^{-3}\right.$ for ${ }^{223} \mathrm{Ra}$ and $0.15 \mathrm{dpm} \mathrm{m}^{-3}$ for ${ }^{224} \mathrm{Ra}$ ) were determined from multiple analyses of prepared standard solutions (acquired from the National Physical Laboratory) and

Table II. Comparison of nearshore and offshore parameters during the 2012 and 2014 field seasons. See Fig. 1 for delineation of offshore versus nearshore samples. Data presented are mean and standard error.

\begin{tabular}{|c|c|c|c|c|}
\hline & \multicolumn{2}{|c|}{2013 surface water } & \multicolumn{2}{|c|}{2014 surface water } \\
\hline & Nearshore $(n=7)$ & Offshore $(n=26)$ & Nearshore $(n=19)$ & Offshore $(n=16)$ \\
\hline Salinity ${ }^{\mathrm{b}, \mathrm{c}, \mathrm{d}}$ & $33.9 \pm 0.0$ & $33.7 \pm 0.1$ & $32.7 \pm 0.1$ & $33.1 \pm 0.0$ \\
\hline Temperature $\left({ }^{\circ} \mathrm{C}\right)^{\mathrm{a}, \mathrm{b}, \mathrm{d}}$ & $0.5 \pm 0.1$ & $-0.1 \pm 0.1$ & $0.7 \pm 0.2$ & $0.9 \pm 0.0$ \\
\hline$\delta \mathrm{D}(\% o)^{\mathrm{b}, \mathrm{d}}$ & $-6.1 \pm 1.2$ & $-6.7 \pm 0.3$ & $-8.1 \pm 0.6$ & $-5.6 \pm 0.2$ \\
\hline${ }^{224} \mathrm{Ra}\left(\mathrm{dpm} \mathrm{m}{ }^{-3}\right)^{\mathrm{b}}$ & $1.7 \pm 1.0$ & $1.2 \pm 0.4$ & $3.6 \pm 0.7$ & $2.1 \pm 0.5$ \\
\hline${ }^{223} \mathrm{Ra}\left(\mathrm{dpm} \mathrm{m}^{-3}\right)^{\mathrm{b}}$ & $0.4 \pm 0.2$ & $0.3 \pm 0.0$ & $0.5 \pm 0.0$ & $0.3 \pm 0.0$ \\
\hline $\mathrm{NH}_{4}^{+}(\mu \mathrm{M})^{\mathrm{a}, \mathrm{b}, \mathrm{c}, \mathrm{d}}$ & $5.2 \pm 0.8$ & $1.4 \pm 0.3$ & $1.0 \pm 0.2$ & $2.1 \pm 0.2$ \\
\hline $\mathrm{HPO}_{4}^{-2}(\mu \mathrm{M})^{\mathrm{b}, \mathrm{c}, \mathrm{d}}$ & $1.4 \pm 0.1$ & $1.5 \pm 0.1$ & $0.7 \pm 0.1$ & $1.2 \pm 0.1$ \\
\hline $\mathrm{H}_{4} \mathrm{SiO}_{4}(\mu \mathrm{M})$ & & & $54.6 \pm 3.0$ & $56.0 \pm 0.7$ \\
\hline
\end{tabular}

Statistically different $(t$-test; $P<0.05):{ }^{a} 2013$ nearshore $v s$ offshore, ${ }^{\mathrm{b}} 2014$ nearshore $v s$ offshore, ${ }^{\mathrm{c}} 2013$ vs 2014 nearshore, ${ }^{\mathrm{d}} 2013 v s 2014$ offshore. 

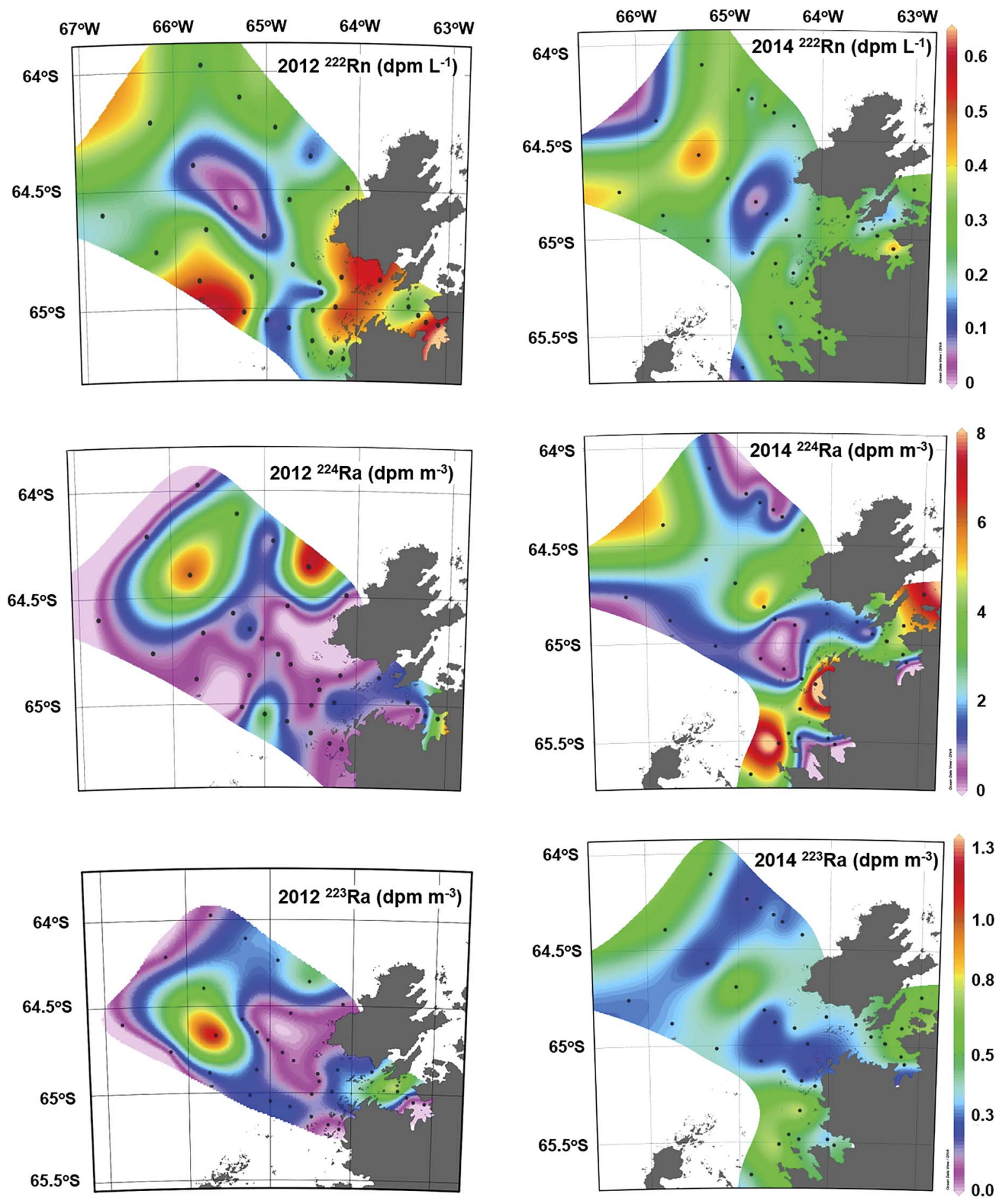

Fig. 5. Spatial distribution of radiotracer surface activities from the 2012 and 2014 cruises. Tracer concentrations follow no particular pattern offshore. Nearshore samples typically show a decreasing concentration with greater distance from the shoreline.

intercalibrated among laboratories participating in GEOTRACES using a similar standard prepared from an International Atomic Energy Agency solution. Analytical uncertainty for individual samples were based on propagated counting statistics, and averaged $7 \%$ and $21 \%$ for ${ }^{224} \mathrm{Ra}$ and ${ }^{223} \mathrm{Ra}$, respectively.

\section{Radon}

Radon analyses were completed by collecting 61 of water at each location and depth prior to any other sample collection to avoid potential degassing from the Niskin bottles. Seawater was siphoned into a 61 Nalgene bottle 

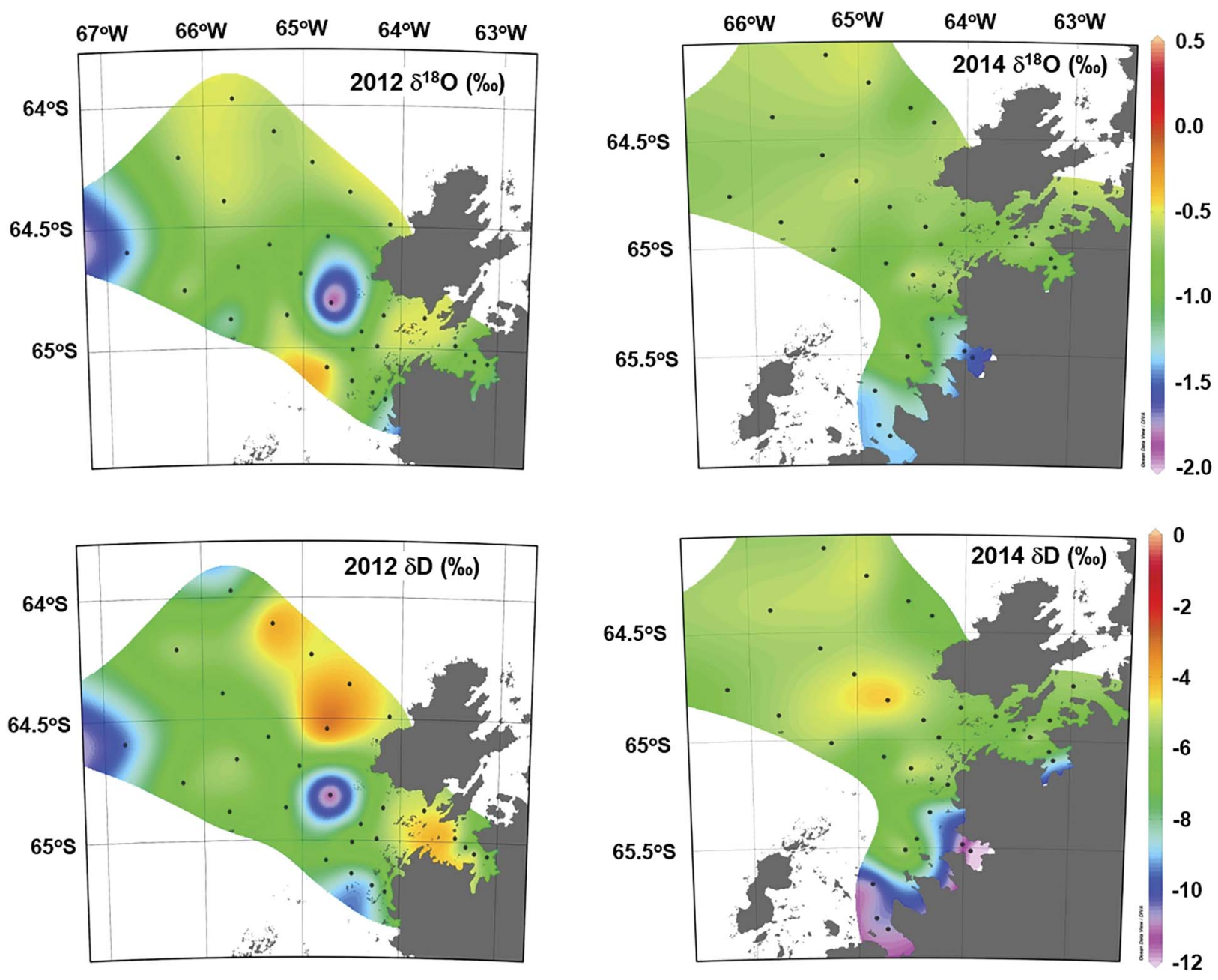

Fig. 6. Spatial distribution of water isotope $\left(\delta \mathrm{O}^{18}, \delta \mathrm{D}\right)$ surface water concentrations from the 2012 and 2014 cruises. All surface samples are reported, including those that are probably outliers leading to a shelf 'bullseye' in 2012. Note more depleted isotopic signatures nearshore during the 2014 cruise.

with a filling-venting cap to minimize radon evasion. Each seawater sample was analysed with a RAD-7 radonin-air monitor (Durridge) via procedures outlined in Lee \& Kim (2006). The RAD-7 uses a silicon semiconductor at ground potential to measure the short-lived Po isotopes emitted by ${ }^{222} \mathrm{Rn}$ decay.

\section{Nutrients, $\delta^{18} O$ and $\delta D$}

A $60 \mathrm{ml}$ seawater sample was collected at each sampling location and depth for nutrient analyses $\left(\mathrm{NO}_{3}{ }^{-}+\mathrm{NO}_{2}{ }^{-}\right.$, $\left.\mathrm{NH}_{4}^{+}, \mathrm{HPO}_{4}{ }^{2-}, \mathrm{H}_{4} \mathrm{SiO}_{4}\right)$. Each sample was syringe filtered on-site through a $0.45 \mu \mathrm{m}$ filter into a $60 \mathrm{ml}$ polypropylene bottle. All sampling materials and bottles were acid-cleaned prior to use. Samples collected were stored at $-20^{\circ} \mathrm{C}$ until analysis on a Lachat Quickchem Autoanalyser.

Dissolved iron $(\mathrm{dFe})$ was sampled from freshwater endmembers using acid-cleaned material and trace metal clean protocols. Samples were pumped immediately from source waters (e.g. groundwater, stream, etc.) through an inline $0.2 \mu \mathrm{m}$ membrane filter into a polyethylene sample bottle using a peristaltic pump to avoid exposure to air. All sampling materials and bottles were acid-cleaned prior to use. Samples were preserved with Optima ultrapure nitric acid and shipped to Skidaway Institute of Oceanography for analysis on a Perkin Elmer NexION 300D ICP-MS.

Water isotope samples were collected at the same time as nutrient samples. To minimize degassing, water was allowed to overflow a $20 \mathrm{ml}$ scintillation vial for $>10 \mathrm{sec}$. After the scintillation vial was completely filled with seawater with no head space, vials were capped, sealed with parafilm and stored inverted at $4^{\circ} \mathrm{C}$. Samples were shipped to Ohio State University for analysis on a Picarro L2130 Wavelength Scanned-Cavity Ring Down Spectrometer water isotope analyser. Calculated values are relative to Vienna Standard Mean Ocean Water (VSMOW) with precision of $0.03 \%$ and $0.1 \%$ for $\delta^{18} \mathrm{O}$ and $\delta \mathrm{D}$, respectively. 

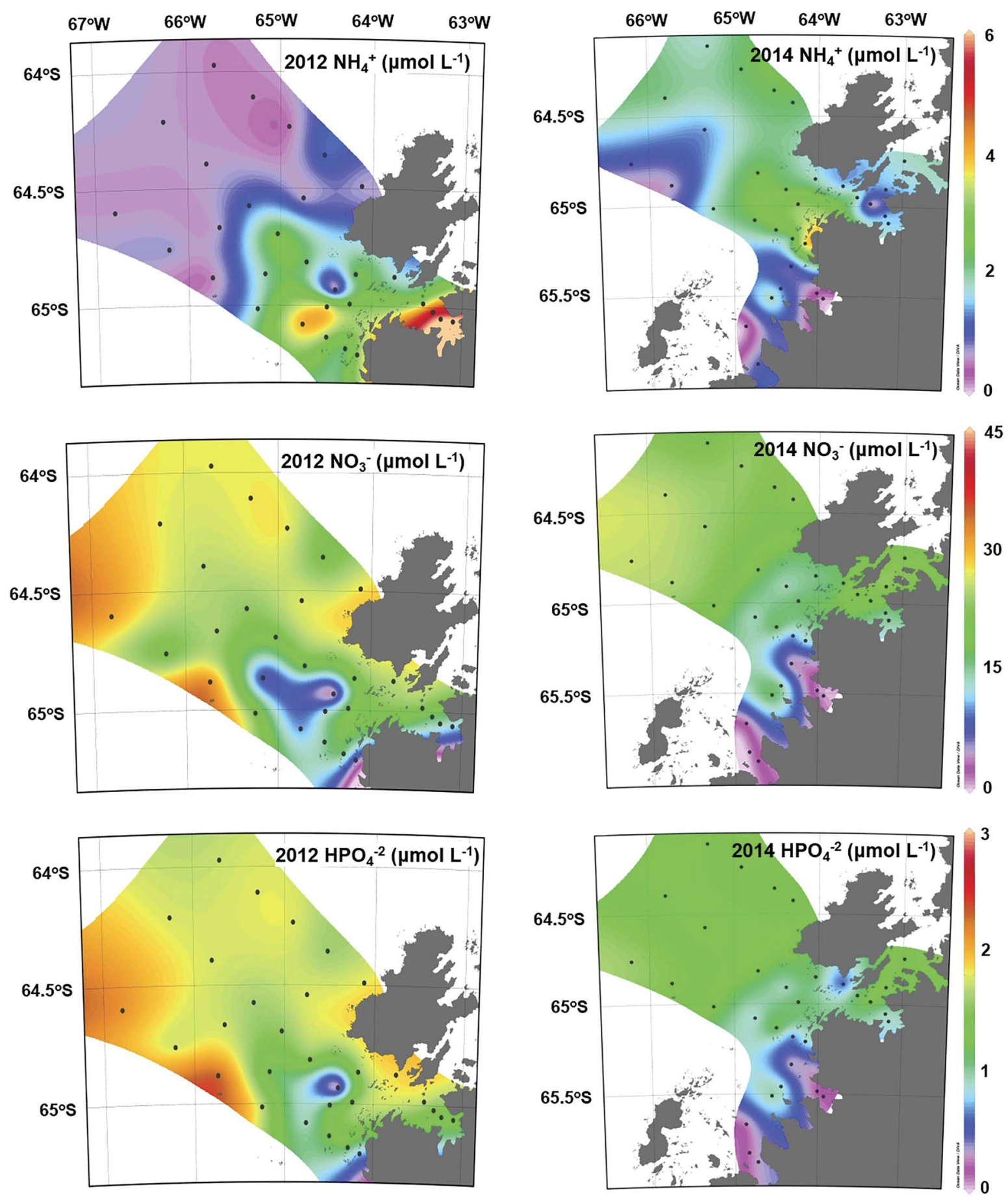

Fig. 7. Spatial distribution of nutrient $\left(\mathrm{NH}_{4}{ }^{+}, \mathrm{NO}_{3}{ }^{-}, \mathrm{HPO}_{4}{ }^{-2}\right)$ surface water concentrations from the 2012 and 2014 cruises. Concentrations nearshore are more depleted in 2014.

\section{Results}

\section{Physical parameters}

Air temperature measured at Palmer Station provides context for differences observed between the two cruises. Average air temperature for one and two months prior to the 2012 cruise (Fig. 2, hatched area) were $-0.3 \pm 1.3^{\circ} \mathrm{C}$ and $-2.2 \pm 3.2^{\circ} \mathrm{C}$, respectively. Average air temperature for one and two months prior to the 2014 cruise (Fig. 2, hatched area) were $1.1 \pm 1.1^{\circ} \mathrm{C}$ and $1.1 \pm 1.4^{\circ} \mathrm{C}$, respectively. Generally, air temperatures were below freezing and more variable prior to the 2012 cruise, and 
above freezing and less variable prior to the 2014 cruise (Fig. 2). Temperatures were significantly higher $(P<0.01)$ during the 2014 cruise.

During the cruises, surface water temperatures varied from $-1.5-2.8^{\circ} \mathrm{C}$, with an average of $0.5^{\circ} \mathrm{C}$. The warmest waters were observed in Flandres Bay and regions closer to shore. The coldest surface temperatures were measured along T3 in 2012 and in Barilari Bay during the February 2014 cruise (Fig. 3). Temperature minima $\left(-2^{\circ} \mathrm{C}\right)$ existed during both field seasons throughout the study area at 50-100 $\mathrm{m}$ depth. These temperature minima were not present closer to the shoreline, where density gradients were less prevalent across the permanent pycnocline at a depth of $\sim 100-150 \mathrm{~m}$ (Fig. 4). Surface salinities ranged from 31.2-34.1 with an average of 33.2. Fresher waters were found closest to shore in Flandres Bay, Beascochea Bay and Barilari Bay (Fig. 3). The surface mixed layer did not extend below $\sim 40 \mathrm{~m}$ depth throughout the study region (Fig. 4). Deep waters (> $60 \mathrm{~m}$ ) within the study area ranged in temperature from $-0.5-1.6^{\circ} \mathrm{C}$, with an average of $1.1^{\circ} \mathrm{C}$. Salinities in deep waters ranged from $34.2-34.7$, with an average of 34.6.

\section{Isotopic tracers}

During the 2012 and 2014 field campaigns, short-lived isotopes (i.e. $\mathrm{Ra}, \mathrm{Rn}$ ) were measured in groundwaters and streams near Palmer Station. In addition, surface waters offshore of Anvers Island and in nearshore fjords were sampled aboard the RV Laurence M. Gould. Groundwater and stream waters had elevated activities of all radiotracers (Table I) relative to nearshore and offshore surface water (Table II). Activities of these freshwater endmembers were as much as three orders of magnitude higher than nearby surface waters.

Surface ${ }^{223,224} \mathrm{Ra}$ activities ranged from $0.1-1.0 \mathrm{dpm} \mathrm{m}^{-3}$ and $0.1-12.8 \mathrm{dpm} \mathrm{m}^{-3}$, respectively (Fig. 5). Similarly, deep water ${ }^{223,224} \mathrm{Ra}$ activities ranged from $0.2-1.7 \mathrm{dpm} \mathrm{m}^{-3}$ and $0.2-16.1 \mathrm{dpm} \mathrm{m}^{-3}$, respectively. Surface ${ }^{222} \mathrm{Rn}$ activities ranged from $0.3-0.8 \mathrm{dpm} 1^{-1}$, while deeper waters

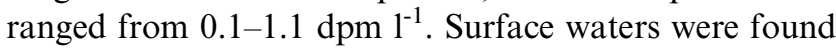
to be enriched in short-lived $\mathrm{Rn}$ and $\mathrm{Ra}$ isotopes in the vicinity of Anvers Island and Flandres Bay in 2012, and nearshore in Barilari and Flandres Bays in 2014 (Fig. 5).

Deuterium values in surface and deep waters ranged from $-12.1--3.7 \%$ and $-11.2--0.5 \%$, respectively. ${ }^{18} \mathrm{O}$ values in surface and deep waters ranged from $-1.9-0.4 \%$ o and $-1.36-0.02 \%$, respectively. The distribution of $\delta^{18} \mathrm{O}$ and $\delta \mathrm{D}$ co-vary. Generally, surface samples nearshore were more depleted relative to stations offshore (Fig. 6, Table II). Gradients in surface water $\delta^{18} \mathrm{O}$ and $\delta \mathrm{D}$ were most prominent in the fjords (Fig. 6). Offshore surface samples showed high variability in the isotopic values, probably an indication of advective mixing.

\section{Nutrients}

Orthophosphate concentrations in surface waters ranged from $0.12-2.3 \mu \mathrm{M}$. Nitrate/nitrite concentrations in surface waters ranged from $4.0-32 \mu \mathrm{M}$. Nitrate/nitrite and phosphate concentrations showed similar patterns (Fig. 7). Generally, bottom water concentrations were higher than surface water values, and surface water concentrations along the coast were lower than offshore waters. Deep water orthophosphate and nitrate/nitrite concentrations ranged from $1.8-2.4 \mu \mathrm{M}$ and $16.8-37 \mu \mathrm{M}$, respectively.

Ammonium concentrations in surface waters ranged from below detection to $6.5 \mu \mathrm{M}$ (Fig. 7). In deeper waters, ammonium concentrations range from below detection to 1.6 $\mu \mathrm{M}$. Patterns in the distribution of ammonium differ from patterns observed in orthophosphate and nitrate/ nitrite, although ammonium was similarly depleted in some areas (Beascochea and Barilari bays). Increased ammonium concentrations in surface waters were observed in the vicinity of Grandidier Channel and in Flandres Bay. Silicate concentrations in surface waters varied from 38-88 $\mu \mathrm{M}$ (Fig. 7). Surface waters in Flandres Bay and in the Gerlache Channel were enriched relative to offshore surface waters and fjords to the south. In deeper waters, silicate concentrations range from $87-108 \mu \mathrm{M}$.

\section{Discussion}

\section{Tracer signatures of freshwater sources}

Along the shoreline of the WAP and nearby islands, fresher water masses were observed in the upper layers of the water column (Figs $3 \& 4$ ). These salinity differences in the upper parts of the water column co-varied with physical and geochemical parameters that have been used to identify glacial melt, such as $\delta^{18} \mathrm{O}$ and our radiotracers (Figs $5 \& 6$ ). The light isotopic signature of glacial ice has been used previously to trace meltwater pulses along the Antarctic continental shelf (Schlosser et al. 1990, Weppernig et al. 1996, Meredith et al. 2008). Groundwaters and surface runoff from glacial melt (i.e. streams) had an average $\delta^{18} \mathrm{O}$ signature of $-11.4 \%$ o and $-10 \%$, respectively, while the average $\delta \mathrm{D}$ was $-89.4 \%$ o and $-78.2 \%$, respectively (Table I).

Groundwaters and streams were enriched in $\mathrm{Ra}$ and $\mathrm{Rn}$ relative to seawater, and depleted in ${ }^{18} \mathrm{O}$. Groundwater samples from Anvers Island had average activities of 3.2 and $83 \mathrm{dpm} \mathrm{m}^{-3}$ for ${ }^{223} \mathrm{Ra}$ and ${ }^{224} \mathrm{Ra}$, respectively, which are high relative to average surface water values observed offshore (Tables I \& II, Fig. 5). Streams were also enriched in $\mathrm{Ra}$ isotopes relative to surface waters along the WAP. On average, streams had activities of 8.2 and $57 \mathrm{dpm} \mathrm{m}^{-3}$ for ${ }^{223} \mathrm{Ra}$ and ${ }^{224} \mathrm{Ra}$, respectively (Table I). Similarly, Rn was enriched in groundwaters and streams 
relative to nearshore and offshore surface waters (Tables I $\&$ II). The relative enrichment of $\mathrm{Ra}$ and $\mathrm{Rn}$ in terrestrially derived waters can be used to identify and evaluate the freshwater (e.g. meltwater) inputs observed along the WAP, assuming other potential sources (e.g. bottom sediments) are taken into account. However, this study has focused on surface waters above the pycnocline in water depths $(200-600 \mathrm{~m})$ that far exceed the surface mixed layer $(\sim 30 \mathrm{~m})$ therefore limiting the potential inputs of these short-lived tracers from bottom sediments or deep water sources.

\section{Tracer variability with proximity to the shoreline}

Changes in surface salinity, temperature and tracer activities vary with the amount of meltwater entering the nearshore environment. These parameters and others change with the progression of the summer as more meltwater enters the nearshore environment. The averages of surface temperature and salinity values (Table II) remain within the limits of AASW defined by Klinck et al. (2004) with the exception of nearshore salinity in 2014 (32.7 \pm 0.1$)$. These waters were significantly fresher on average than AASW and the other waters measured during this study, which suggests that local glacial melt inputs are mixing with nearshore surface waters. Data from the December 2012 cruise suggest little change in surface seawater characteristics with distance from the shoreline. This cruise took place during the early weeks of the summer when the melt season was just beginning. A notable difference is that offshore waters were much cooler than surface waters nearshore. Glacial melt signals were not as prominent across the shelf compared to gradients in nearshore waters. The 2014 cruise took place during the latter phases of the summer. At this point in the season, there were notable differences in the physical and geochemical characteristics of surface seawater nearshore relative to offshore waters. Nearshore surface waters had lower salinity, temperature, $\delta^{18} \mathrm{O}$ and $\delta \mathrm{D}$ values, and higher ${ }^{223,224} \mathrm{Ra}$ activities relative to offshore surface waters. These changes probably document an increased meltwater influence with the progression of the summer and the utility of these geochemical tracers in identifying meltwater input. The location and intensity of meltwater inputs can impact and influence the prolific phytoplankton blooms that take place along the WAP (Dierssen et al. 2002). In order to gain an understanding of how quickly these water masses can be distributed along the WAP, mixing models were employed to evaluate coastal and cross-shelf mixing.

\section{Nearshore mixing}

Radon and short-lived Ra were used to estimate mixing in nearshore waters. Assuming the source of these tracers is nearshore (e.g. meltwater) and changes in activity are a function of mixing with offshore water of lower activity and radioactive decay, then the change in activity can be modelled via:

$$
A_{x}=A_{o} e^{-x \sqrt{\lambda / K_{h}}}
$$

where $A_{x}$ is the activity at distance $x$ from the coast, $A_{0}$ is the activity at the coast $(\mathrm{x}=0), K_{h}$ is the mixing coefficient and $\lambda$ is the decay constant (Moore 2000). Additional assumptions include: i) the system is at steady state, ii) a constant source of tracer only at the landward boundary $\left(A_{0}\right)$ and iii) advection is not significant across the distance modelled. We are confident in these assumptions given that no influence of advection was observed (i.e. no deviation from the linear trend of $1 n$ (tracer) with distance) and the water depth (200-600 m) far exceeds the surface mixed layer $(\sim 30 \mathrm{~m})$ limiting new tracer inputs from bottom sediments. Although shortlived $\mathrm{Ra}$ isotopes have typically been employed with this method (Moore 2000, Annett et al. 2013), assuming
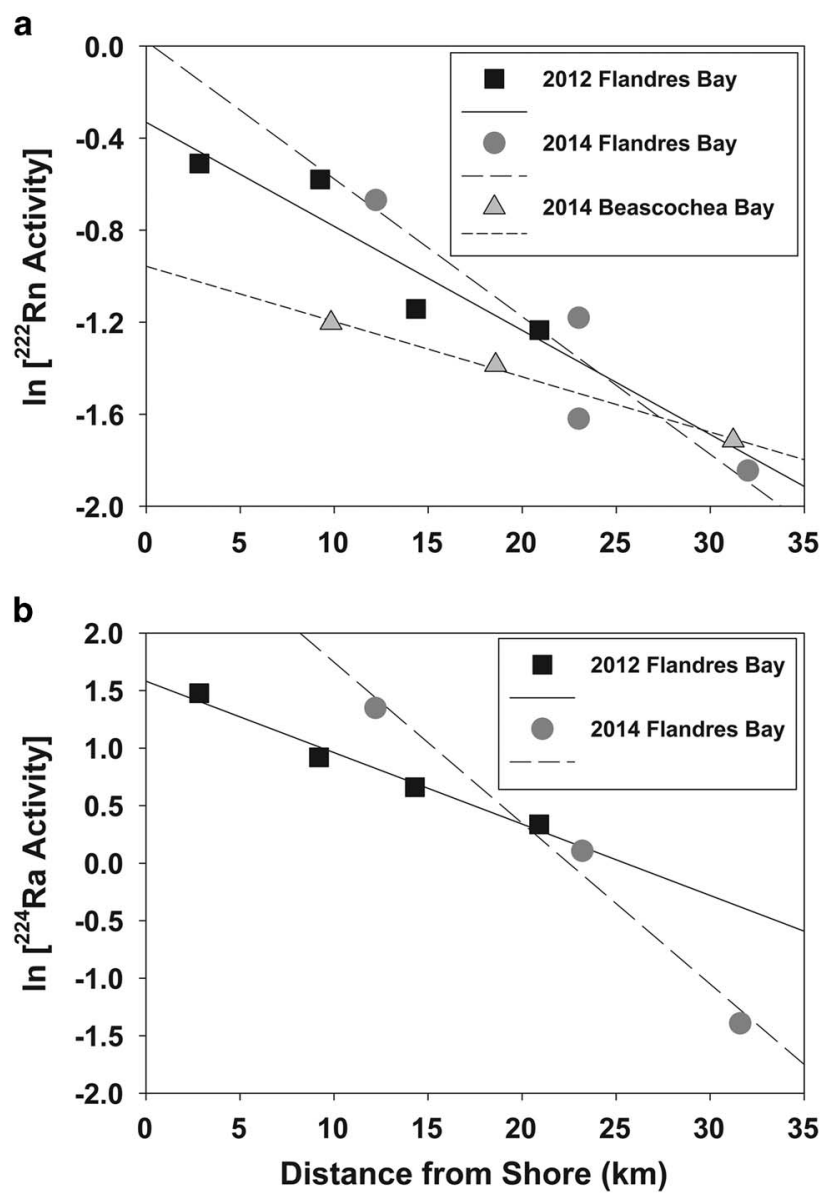

Fig. 8. The a. $\ln ^{222} \mathrm{Rn}$ and b. $\ln ^{224} \mathrm{Ra}$ profiles from Flandres Bay in 2012 and 2014, and well as Beascochea Bay in 2014. Lines represent the best-fit trend line used to calculate mixing rates for each tracer during each sampling year. 
atmospheric evasion is minimal, radon should provide similar results as the source of the tracers is assumed to be the same (e.g. meltwater). Mixing rates were estimated within two fjords (i.e. Flandres and Beascochea bays) where degassing was reduced $\left(<0.1 \mathrm{dpm} \mathrm{m}{ }^{-2} \min ^{-1}\right)$ due to low winds $\left(<5 \mathrm{~m} \mathrm{~s}^{-1}\right)$ based on the calculated flux of $\mathrm{Rn}$ from the sea surface to the atmosphere for the 24 hours prior to sample collection.

In Flandres Bay, ${ }^{222} \mathrm{Rn}$-derived mixing rates were $1020 \pm 300$ and $570 \pm 160 \mathrm{~m}^{2} \mathrm{~s}^{-1}$ for the 2012 and 2014 cruises, respectively, while ${ }^{224} \mathrm{Ra}$-derived mixing rates were $570 \pm 60$ and $110 \pm 20 \mathrm{~m}^{2} \mathrm{~s}^{-1}$, respectively, for the same period (Fig. 8). Both tracers show a decreased mixing rate during 2014 and may represent seasonal variability. Mixing in Beascochea Bay was estimated at $3600 \pm 200 \mathrm{~m}^{2} \mathrm{~s}^{-1}$ (Fig. 8) using measurements spanning a distance of $\sim 31 \mathrm{~km}$. Similar to Flandres Bay, Beascochea Bay is flanked by glaciers but opens to the relatively unprotected Grandidier Channel at its mouth.

Calculated mixing rates were within the range of other rates calculated along the WAP to the north where Dulaiova et al. (2009) estimated mixing rates via Ra isotopes along the South Shetland Islands of 596-63 $000 \mathrm{~m}^{2} \mathrm{~s}^{-1}$ in open ocean waters. This location is where the Antarctic Circumpolar Current approaches the northern edge of the peninsula. However, south of our study area, Annett et al. (2013) calculated mixing rates using Ra isotopes within Marguerite Bay of $0.13-1.0 \mathrm{~m}^{2} \mathrm{~s}^{-1}$, which are several orders of magnitude lower than those calculated in this study and probably reflect the lowvelocity circulation dynamics of the more protected embayment of Marguerite Bay.

Estimating cross-shelf mixing via ${ }^{223,224} \mathrm{Ra}$ and ${ }^{222} \mathrm{Rn}$ proved to be more problematic. Mixing models using terrestrially derived tracers assume that there is a single source of tracer emanating from the continental margin and that vertical and lateral (e.g. along-shelf) advective transport is negligible. Surface currents and circulation dynamics across the continental margin are much more complex than the models used here to evaluate them. The ADCP data collected as part of this study and composite data presented by Savidge \& Amft (2009) show that circulation patterns are complicated, and vary over different timescales. Recent surface current measurements via high-frequency radar demonstrates the spatial and temporal complexity of currents in this region, with large short-term areas of convergence and divergence, intermixed with cross-shelf and along-shelf advection (Kohut et al. 2016). However, unlike the shelf, the fjords provide an area where the assumptions essential for this type of unidirectional circulation model are more plausible. Because the offshore areas are more susceptible to advective mixing in the along- and cross-shore directions, mixing rates are probably much higher than those estimated here for the fjords.

\section{Seasonal variability: nutrient transport and shelf productivity}

As noted previously, the December 2012 survey was conducted at the beginning of the summer when the surface waters ranged in salinity from 32.6-34.8 with a mean of 33.7. Radium values in surface waters averaged $1.5 \mathrm{dpm} \mathrm{m}^{-3}$. The average atmospheric temperature for November and December 2012 was $-2.22^{\circ} \mathrm{C}$ (Fig. 2). The 2014 cruise took place during the latter part of February, as the summer season was coming to an end. Surface waters ranged in salinity from 31.2-33.6 and averaged 32.9. For surface waters in 2014, Ra values averaged $3.03 \mathrm{dpm} \mathrm{m}^{-3}$. January and February 2014 atmospheric temperatures at Palmer Station averaged $1.1^{\circ} \mathrm{C}$ (Fig. 2). As the season progresses, air temperatures $>0{ }^{\circ} \mathrm{C}$ are more common and there are fewer hours of darkness. The increased temperatures and exposure to sunlight enhance glacial melting, progressively releasing vast quantities of meltwater into the surface ocean.

The highest fluorescence values $\left(6-8 \mathrm{mg} \mathrm{m}^{-3}\right)$ reported in this study were measured in the Grandidier Channel seaward of Barilari Bay. These waters were enriched in ${ }^{222} \mathrm{Rn},{ }^{223} \mathrm{Ra}$ and ${ }^{224} \mathrm{Ra}$ relative to surface waters offshore where fluorescence (e.g. primary productivity) was lower $\left(0-2 \mathrm{mg} \mathrm{m}^{-3}\right)$. These nearshore waters were clearly fresher, colder, and depleted in ${ }^{18} \mathrm{O}$ and $\mathrm{D}$ relative to adjacent surface waters (Fig. 6), suggesting that glacial melt comprises a higher percentage of surface waters in the Grandidier Channel near Barilari Bay. Given the higher macro and micronutrient concentrations measured in these terrestrially derived waters, it is hypothesized that nutrient transport via glacial melt plays a role in fuelling the observed primary productivity (e.g. higher fluorescence).

Several studies (Moore 1996, Dierssen et al. 2002, Windom et al. 2006) have linked the terrestrial environment and primary productivity in the surface ocean through submarine groundwater discharge with respect to macro and micronutrients. Unlike the temperate and tropical environments where groundwater discharge studies have focused, the WAP is quite different in that it has a vast reservoir of frozen water covering the majority of the land surface that partially melts during summer months. This study suggests that primary productivity along the WAP could be linked to nutrients provided by these seasonal meltwater inputs following different delivery pathways. Mixing rates in the surface waters observed in nearby Beascochea Bay and within Flandres Bay are within the range of those calculated along the northern reaches of the WAP (Dulaiova et al. 2009), and higher than those calculated in the more isolated Marguerite Bay (Annett et al. 2013). Although mixing rates are probably much higher across the shelf proper, nutrients appear to be quickly taken-up nearshore prior to export offshelf, with potential cross-shelf transport via particulate organic forms rather than dissolved inorganic forms of those nutrient species. 
Our analysis indicates that the nitrate, ammonium and orthophosphate concentrations are statistically different between the nearshore and offshore samples in 2014, with the offshore samples having higher concentrations (Table II and Fig. 7; Fig. 1 dotted line represents nearshore/offshore delineation). This may suggest either enhanced glacial flux from more far afield, nearshore biological uptake or the influence of upwelled, more nutrient-rich water added offshore. The 2014 nearshore waters have a DIN:P:Si molar ratio of 17:1:78, while the offshore waters have 18:1:47. There has been little research on either subaerial or subglacial melt geochemistry. Surface runoff from glacial melt from Livingston Island to the north of the study area at $62^{\circ} 40^{\prime} \mathrm{S}$ has DIN:P:Si molar ratios of 5.3:1:54 (Toro et al. 2007), while the only other subglacial water analysis from the West Antarctic Ice Sheet has a ratio of 1.1:1:41 (Christner et al. 2014, Michaud et al. 2016). In comparison, surface runoff from glacial melt collected near Palmer Station has an average DIN:P:Si molar ratio of 39:1:32, while groundwater is 31:1:7 (Table I). Clearly, our surface water data are much more DIN depleted relative to both $\mathrm{P}$ and $\mathrm{Si}$ of the groundwaters and stream waters around Palmer Station. Whether this suggests preferential uptake of $\mathrm{N}$ in these waters or just significant geochemical variabilities in glacial melt requires further investigation. Given the observation that the means of the N:P for both the nearshore and offshore waters are close to the Redfield ratio of 16:1, these waters have probably been modified by biological processes even in close proximity to the glacial sources.

In this study, higher surface fluorescence values (2-8 $\mathrm{mg} \mathrm{m}^{-3}$ ) were observed close to the shoreline where isotopic tracers suggest glacial melt inputs are present. Farther offshore, surface fluorescence values were lower $\left(0-2 \mathrm{mg} \mathrm{m}^{-3}\right)$. Given this spatial distribution, it is possible that the extent and location of phytoplankton blooms are controlled by the location, intensity and mixing of meltwater inputs along the coast. Circulation dynamics, especially those that control the distribution of meltwater, are impacted by changes in surface water temperature and salinity. As atmospheric and oceanic temperatures along the WAP rise, the volume of meltwater that enters the surface ocean will certainly increase. This change in meltwater dynamics with respect to the duration of warmer atmospheric temperatures is observed in this study over the changing seasons, although the same concepts could be applied over longer time scales.

\section{Conclusions}

Terrestrially derived water masses introduce and transport macro and micronutrients along and across the shelf of the WAP. As atmospheric temperatures along the WAP rise, the increasing frequency and intensity of meltwater pulses along the WAP have the potential to profoundly impact global carbon and climate cycles. Similar to other coastal systems around the globe, terrestrial water can be identified via natural tracer concentrations $\left({ }^{223,224} \mathrm{Ra},{ }^{222} \mathrm{Rn}, \delta^{18} \mathrm{O}\right.$, $\delta D)$. Groundwater and surface runoff from glacial meltwaters were significantly enriched in $\mathrm{Ra}$ and $\mathrm{Rn}$ relative to seawater, and depleted in ${ }^{18} \mathrm{O}$ and $\mathrm{D}$.

These tracers should vary in concentration as a function of meltwater delivery to coastal waters. Given the difference in season between the two cruises (early summer in 2012 and late summer in 2014), the higher activities in $\mathrm{Ra}$ and $\mathrm{Rn}$ observed nearshore in 2014 are attributed to an increase in meltwater production and discharge. This increased freshwater delivery was also seen in the salinity and water isotopes nearshore compared to the offshore values in 2014.

Calculated horizontal mixing rates of water masses within glacial fjords along the WAP via ${ }^{224} \mathrm{Ra}$ and ${ }^{222} \mathrm{Rn}$ ranged from $110-3600 \mathrm{~m}^{2} \mathrm{~s}^{-1}$. Mixing rates estimated here were within the range of other rates calculated along the WAP and suggest a rapid transport mechanism for moving meltwater offshore. Based on data collected offshore of Anvers Island during the 2012-13 and 2013-14 summers, the flux of biolimiting nutrients from the Antarctic continent across the continental shelf was evaluated. More work is needed to further evaluate the flux and important biogeochemical elements such as Fe to the surface waters along the WAP to gain a true understanding of how continental inputs play a role in this globally important ecological system.

\section{Acknowledgements}

We would like to thank the captain and crew of the RV Laurence M. Gould, the scientists and support staff of Palmer Station, the US Antarctic Program, and the many graduate students who not only assisted in sample analyses at ECU and CCU but devoted significant amounts of time to assist with field efforts in the Antarctic. We thank Sue Welch, Kelsey Dailey and Elsa Saelens for their help in the laboratory analysis at Ohio State University. This research was funded by the National Science Foundation, grant number ANT-1142090 (DRC/KN) and ANT-1142059 (WBL). The authors appreciate the support of the University of Wisconsin-Madison Automatic Weather Station Program for the dataset, data display and information, NSF grant number ANT-1245663. J.P. Walsh and two anonymous reviewers are acknowledged for suggestions that improved the manuscript.

\section{Author contributions}

DRC and KN conceived the project and led field efforts. JC, RNP and LEP managed the radionuclide analysis in the field and at their respective universities. WBL analysed deuterium and ${ }^{18} \mathrm{O}$ of all water samples at Ohio State University. All authors contributed to the discussion of results and writing of the manuscript. 


\section{References}

Annett, A., Henley, S., van Beek, P., Souhaut, M., Ganeshram, R., Venables, H., Meredith, M. \& Geibert, W. 2013. Use of radium isotopes to estimate mixing rates and trace sediment inputs to surface waters in northern Marguerite Bay, Antarctic Peninsula. Antarctic Science, 25, 445-456.

Bhatia, M., Kujawinski, E., Das, S., Breier, F., Henderson, P. \& Charette, M. 2013. Greenland meltwater as a significant and potentially bioavailable source of iron to the ocean. Nature Geoscience, 6, 274-278.

Christner, B.C., Priscu, J.C., Achberger, A.M., Barbante, C., Carter, S.P., Christianson, K., Michaud, A.B., Mikucki, J.A, Mitchell, A.C., Skidmore, M.L. \& Vick-Majors, T.J.; WISSARD Sci Team 2014. A microbial ecosystem beneath the West Antarctic Ice Sheet. Nature, 512, 310-313.

Cook, A.J., Fox, A.J., Vaughan, D.G. \& Ferrigno, J.G. 2005. Retreating glacier fronts on the Antarctic Peninsula over the past half-century. Science, 308, 541-544.

Dierssen, H., Smith, R. \& Vernet, M. 2002. Glacial meltwater dynamics in coastal waters west of the Antarctic Peninsula. Proceedings of the National Academy of Science of the United States of America, 99, 1790-1795.

Ducklow, H.W., Clarke, A., Dickhut, R., Doney, S.C., Geise, H., Huang, K., Martinson, D.G., Meredith, M.P., Moeller, H.V., Montes-Hugo, M., Schofield, O., Stammerjohn, S.E., Steinberg, D. \& Fraser, W. 2012. The marine system of the Western Antarctic Peninsula. In Rogers, A.D., Johnston, N.M., Murphy, E.J. \& Clarke, A., eds. Antarctic ecosystems: an extreme environment in a changing world. Chichester: Wiley-Blackwell, 121-159.

Dulaiova, H., Arldelan, M.V., Henderson, P.V. \& Charette, M.A. 2009. Shelf-derived iron inputs drive biological productivity in the southern Drake Passage. Global Biogeochemical Cycles, 10.1029/ 2008 GB003406.

Hawkings, J.R., Wadham, J.L., Tranter, M., Raiswell, R., Benning, L. G., Statham, P.J., Tedstone, A., Nienow, P., Lee, K. \& Telling, J. 2014. Ice sheets as a significant source of highly reactive nanoparticulate iron to the oceans. Nature Communications, 10.1038/ncomms4929.

KING, J.C. 1994. Recent climate variability in the vicinity of the Antarctic Peninsula. International Journal of Climatology, 14, 357-369.

Klinck, J.M., Hofmann, E.E., Beardsley, R.C., Salihoglu, B. \& HowARD, S. 2004. Water-mass properties and circulation on the west Antarctic Peninsula continental shelf in austral fall and winter 2001. Deep-Sea Research - Topical Studies in Oceanography, 51, 1925-1946.

Kohut, J., Miles, T., Bernard, K., Fraser, W., Patterson-Fraser, D., Oliver, M., Cimino, M., Winsor, P., Statscewich, H. \& Fredu, E. 2016. Project CONVERGE: impacts of local oceanographic processes on Adélie penguin foraging ecology. OCEANS 2016 MTS/ IEEE Monterey, 10.1109/OCEANS.2016.7761152.

Kunz, M., King, M.A., Mills, J.P., Miller, P.E., Fox, A.J., VAughan, D.G. \& Marsh, S.H. 2012. Multi-decadal glacier surface lowering in the Antarctic Peninsula. Geophysical Research Letters, $10.1029 / 2012$ GL052823.

LeE, J.M. \& KIM, G. 2006. A simple and rapid method for analyzing radon in coastal and ground waters using a radon-in-air monitor. Journal of Environmental Radioactivity, 89, 219-228.

Lyons, W.B., Dailey, K.R., Welch, K.A., Deuerling, K.M., Welch, S.A. \& McKNight, D.M. 2015. Antarctic streams as a potential source of iron for the Southern Ocean. Geology, 43, 1003-1006.

Meredith, M.P., Brandon, M.A., Wallace, M.I., Clarke, A., Leng, M.J., Renfrew, I.A., van LiPZig, N.P.M. \& King, J.C. 2008. Variability in the freshwater balance of northern Marguerite Bay, Antarctic Peninsula: results from $\delta^{18} \mathrm{O}$. Deep-Sea Research - Topical Studies in Oceanography, 55, 309-322.
Meredith, M.P., Venables, H.J., Clarke, A., Ducklow, H.W., Erickson, M., Leng, M.J., Lenaerts, J.T.M. \& van den Broeke, M.R. 2013. The freshwater system west of the Antarctic Peninsula: spatial and temporal changes. Journal of Climate, 26, 1669-1684.

Michaud, A.B., Skidmore, M.L., Mitchell, A.C., Vick-Majors, T.J., Barbante, C., Turetta, C., vanGelder, W. \& Priscu, J.C. 2016. Solute sources and geochemical processes in Subglacial Lake Whillans, West Antarctica. Geology, 44, 347-350.

Moffat, C., Beardsley, R.C., Owens, B. \& van Lipzig, N. 2008. A first description of the Antarctic Peninsula coastal current. Deep-Sea Research - Topical Studies in Oceanography, 55, 277-293.

Moore, W.S. 1996. Large groundwater inputs to coastal waters revealed by ${ }^{226} \mathrm{Ra}$ enrichments. Nature, 380, 612-614.

Moore, W.S. 2000. Determining coastal mixing rates using radium isotopes. Continental Shelf Research, 20, 1993-2007.

Moore, W.S. \& ARnold, R. 1996. Measurement of ${ }^{223}$ Ra and ${ }^{224}$ Ra in coastal waters using a delayed coincidence counter. Journal of Geophysical Research - Oceans, 101, 1321-1329.

MorRis, E.M. \& VAughan, D.G. 2003. Spatial and temporal variation of surface temperature on the Antarctic Peninsula and the limit of viability of ice shelves. Antarctic Research Series, 79, 61-68.

SAvidge, D.K. \& Amft, J.A. 2009. Circulation on the West Antarctic Peninsula derived from 6 years of shipboard ADCP transects. Deep-Sea Research - Oceanographic Research Papers, 56, 1633-1655.

Schlosser, P., Bayer, R., Foldvik, A., Gammelsrød, T., Rohardt, G. \& MüNNICH, K.O. 1990. Oxygen 18 and helium as tracers of ice shelf water and water/ice interaction in the Weddell Sea. Journal of Geophysical Research - Oceans, 95, 3253-3263.

Schofield, O., Ducklow, H., Martinson, D., Meredith, M.P., Moline, M. \& Fraser, W.R. 2010. How do polar marine ecosystems respond to rapid climate change? Science, 328, 1520-1523.

Steig, E.J., Schneider, D.P., Rutherford, S.D., ManN, M.E., Comiso, J.C. \& SHINDELL, D.T. 2009. Warming of the Antarctic ice sheet surface since the 1957 International Geophysical Year. Nature, 457, 459-463.

Takahashi, T., Sweeney, C., Hales, B., Chipman, D.W., Newberger, T., Goddard, J.G., Iannnuzzi, R.A. \& Sutherland, S.C. 2012. The changing carbon cycle in the Southern Ocean. Oceanography, 25, 26-37.

Toro, M., Camacho, A., Rochera, C., Rico, E., Banon, M., Fernandez-Valiente, E., Marco, E., Justel, A., Avendano, M.C., Ariosa, Y., Vincent, W.F. \& Quesada, A. 2007. Limnological characteristics of the freshwater ecosystems of Bayers Peninsula, Livingston Island, in Maritime Antarctica. Polar Biology, 30, 635-649.

Turner, J., Colwell, S.R., Marshall, G.J., Lachlan-Cope, T.A., Carleton, A.M., Jones, P.D., Lagun, V., Reid, P.A. \& Iagovkina, S. 2005. Antarctic climate change during the last 50 years. International Journal of Climatology, 25, 279-294.

Vaughan, D.G., Marshall, G.J., Connolly, W.M., Parkinson, C.L., Mulvaney, R., Hodgson, D.A., King, J.C., Pudsey, C.J. \& Turner, J. 2003. Recent rapid regional climate warming on the Antarctic Peninsula. Climatic Change, 60, 243-274.

Wadham, J., De’ath, R., Monteiro, F.M., Tranter, M., Ridgwell, A., Raiswell, R. \& TulaczyK, S. 2013. The potential role of the Antarctic ice sheet in global biogeochemical cycles. Earth and Environmental Science Transactions of the Royal Society of Edinburgh, 104, 55-67.

Weppernig, R., Schlosser, P., Khatiwala, S. \& Fairbanks, R.G. 1996. Isotope data from Ice Station Weddell: implications for deep water formation in the Weddell Sea. Journal of Geophysical Research Oceans, 101, $25723-25739$.

Windom, H., Moore, W.S., Niencheski, L.F. \& Jahrike, R. 2006. Submarine groundwater discharge: a large, previously unrecognized source of dissolved iron to the South Atlantic Ocean. Marine Chemistry, 102, 252-256. 